\title{
Stylistics Within EFL/ESL Contexts
}

\author{
Suhair Al Alami \\ Al Ghurair University, Dubai, UAE
}

\begin{abstract}
The current paper aims to offer a thought-provoking idea on how literary texts can promote English as a foreign language or English as a second language (EFL/ESL) learners' language proficiency. With the ultimate goal of emphasizing quality education in mind, the paper adopts the idea that literature plays an essential role in EFL/ESL contexts. Generally speaking, there are three main merits for a literary education program; namely, developing learners' scope of literary understanding and critical judgment for aesthetic purposes, presenting a broad spectrum of the ideals as expressed in the world's great works, and improving all aspects of the comprehension process: affective consideration, readiness consideration, and so on. Providing learners with literature experiences is, therefore, central to effective instruction. Adopting this view, the paper seeks some convincing answers to the following questions: (1) How can EFL/ESL practitioners maximize the effectiveness of utilizing literary texts to promote students' language proficiency? (2) How can EFL/ESL practitioners maximize the effectiveness of utilizing literary texts through employing a stylistics approach? To exemplify these issues, the paper takes a short story written by Thomas Wolfe “The Far and the Near", and presents the author's proposed procedure for discussing with literary texts.
\end{abstract}

Keywords: EFL/ESL, language proficiency, literary texts

\section{Introduction}

The current paper aims to offer a thought-provoking idea on how literary texts can promote English as a foreign language or English as a second language (EFL/ESL) learners' language proficiency. With the ultimate goal of emphasizing quality education in mind, the paper adopts the idea that literature plays an essential role in EFL/ESL contexts. Adopting this view, the paper seeks some convincing answers to the following questions:

(1) How can EFL/ESL practitioners maximize the effectiveness of utilizing literary texts to promote students' language proficiency?

(2) How can EFL/ESL practitioners maximize the effectiveness of utilizing literary texts through employing a stylistics approach?

To exemplify these issues, the paper takes a short story written by Thomas Wolfe "The Far and the Near", and presents the author's proposed procedure for discussing literary texts within EFL/ESL contexts.

\section{Literature Review: Stylistics Approach}

A number of specialists recommended employing a stylistics approach in the EFL/ESL classroom. What does a stylistics approach mean and entail? Both Busse and Mclntyre (2010) explained that stylistics in its most general sense refers to "the study of style in language and how this results from the intra-linguistic features of a

Suhair Al Alami, lecturer, Ph.D., Department of Foundation and General Studies, Al Ghurair University. 
text in relation to non-linguistic factors such as author, genre, historical period, and so on” (p. 6). According to Leech (2010), stylistics can simply be defined as a "way of using language” (p. 17). When we examine language style, we talk about the style used in a certain textual domain, corpus for example, or the style of a particular text or an extract from a particular text. Busse (2010) proposed that new historical stylistics should be considered as a combined discipline of "linguistic description and literary interpretation", characterized by being functional and formal. What is more, this inter-discipline offers theoretical explorations along with practical applications. A new historical stylistic analysis of a text presumes an adequate knowledge of the context, the period, and the language in which the text is/was produced. Some context-related information guides our reading of a text, generic knowledge for example.

Depicting stylistics in today's world, Carter (2010) thought that it has a significant role to play in relation to methodology in the instruction of literature, and accordingly, in pedagogy developments in both first and second language teaching contexts. Amongst the most prominent developments is focus on "textual transformations" whereby comparative text analysis can be used through rewriting a literary text from different positions, hence, translating the text from textual to dramatic, verbal to visual, or spoken to written. Looked at from Prieto's (2010) point of view, a stylistics-inspired pedagogy of both literary and non-literary texts has the advantage of providing learners with genuine chances for enhancement. Speaking of real-life language functions, such genuine chances are of great benefit in relation to enriching/expanding knowledge: creative, analytical as well as critical.

Warner (2010) discussed how pragmatic stylistics—an interdisciplinary branch of literary linguistic study that deals with literary texts as "social acts of interactive communication"-can function as a methodological basis for a pedagogical strategy of what can be referred to as "contact pragmatics". According to Warner, contact pragmatics can be defined as the literary work's relation to both "intended" and "non-intended readers" as well as the convergence of these universes of expectation. Contact pragmatics stresses the relations between linguistic function and form, and as such, can be employed to promote learners' sensitivity to the use of linguistic choices, enabling them to recognize interpretation in certain social and historical contexts.

Zyngier and Fialho (2010) explained that one of the problems with literature instruction and pedagogical stylistics is their divorce from theories of education. Of great importance for instructors to consider are both the instructional content and the context in which it is conducted; the social conditions in which they teach. Critical pedagogy is likely to help enhance literary awareness in an EFL stylistic context. If learners' voices can lead to informing effective instructional strategies, both instructors and learners reflect on what is taking place in class, considering what has gone wrong or has not been implemented effectively, as well as how and what action to take instead. What is more, the relationship between instructors and learners has to be based on mutual understanding and respect rather than superior to inferior relations. Thus, there has to be some intimate bonds between both parties. Lastly, the class has to be a healthy environment encouraging autonomy learning of major types: cultural, critical, and emotional.

Stockwell (2007) mentioned that due to its capacity for teaching English in EFL/ESL contexts in an engaging way, literary stylistics has achieved success throughout the world. Placing "lexico-grammatical" principles in the context of patterns of meaning as in authentic texts has allowed instructors to engage learners with formal grammar in discourse, whilst maintaining the students' interest. The accessibility of an enabling method to allow learners quickly to engage in analysis is the main reason for the success of stylistics.

As seen by Cook (2003), literary stylistics has proved to be effective in EFL/ESL contexts; it links linguistic choices to their effects upon the reader, as well as raises awareness not only of the importance of 
exact wording, but also of how there is far more at stake in the use of language than the literal meaning of the words. Stylistic analyses tend to highlight three related aspects of literary language; namely, its patterning of linguistic units to create rhymes, rhythms, and parallel constructions, its frequent deviation from the norms of more everyday language use, and the way in which the form of the words seems to intensify the meaning.

According to Crawshaw (1996), the study of stylistics is an integrated discipline that brings together the complementary domains of linguistics, psychology, and sociology. Any utterance or text, fictional or otherwise, takes place or is created by a speaker/author in a given context, and is articulated in a particular form to represent an intention or view of the world. The form of the message is a product both of context and of intention, just as intention can be understood only as a function of context and form.

Sensitivity to literature, Short (1983) explained, it can be taught by providing the student with a descriptive tool applicable to any literary passage, by means of which he can assess the deviance and richness of the text against the norms of everyday language. This is valuable to the foreign learner in particular because it enhances his appreciation by reinforcing knowledge of the regularities he will meet in non-literary language. Instead of leaping into interpretation and then evaluation, students should be urged to devote more time to explicit description, over which they are more likely to agree. Hence, stylistic analysis should be central to the teaching of literature, since it is only by demonstrating the explicit link between linguistic structures and meaning/effect that we will understand how literature works.

\section{Literary Texts Within EFL/ESL Contexts}

This part of the paper presents a short story along with a proposed procedure, which the author thinks can be of use and interest when discussing literary texts within EFL/ESL contexts.

\section{Literary Text (Short Story): “The Far and the Near” by Thomas Wolfe}

1. On the outskirts of a little town upon a rise of land that swept back from the railway there was a tidy little cottage of white boards, trimmed vividly with green blinds. To one side of the house there was a garden neatly patterned with plots of growing vegetables, and an arbor for the grapes, which ripened later in August. Before the house there were three mighty oaks, which sheltered it in their clean and massive shade in summer, and to the other side there was a border of gay flowers. The whole place had an air of tidiness, thrift, and modest comfort.

2. Every day, a few minutes after two o'clock in the afternoon, the limited express between two cities passed this spot. At that moment the great train, having halted for a breathing space at the town near by, was beginning to lengthen evenly into its stroke, but it had not yet reached the full drive of its terrific speed. It swung into view deliberately, swept past with a powerful swaying motion of the engine, a low smooth rumble of its heavy cars upon pressed steel, and then it vanished in the cut. For a moment the progress of the engine could be marked by heavy bellowing puffs of smoke that burst at spaced intervals above the edges of the meadow grass, and finally nothing could be heard but the solid clacking tempo of the wheels receding into the drowsy stillness of the afternoon.

3. Every day for more than twenty years, as the train had approached this house, the engineer had blown on the whistle, and every day, as soon as she heard this signal, a woman had appeared on the porch of the little house and waved to him. At first she had a small child clinging to her skirts, and now this child had grown to full womanhood, and every day she, too, came with her mother to the porch and waved.

4. The engineer had grown old and gray in service. He had driven his great train, loaded with its weight of lives, across the land ten thousand times. His own children had grown up and married, and four times he had seen before him on the tracks the ghastly dot of tragedy converging like a cannon ball to its eclipse of horror at the boiler head-a light spring wagon filled with children, with its clustered row of small stunned faces; a cheap automobile stalled upon the tracks, set with the wooden figures of people paralyzed with fear; a battered hobo walking by the rail, too deaf and old to hear the whistle's warning; and a form flung past his window with a scream-all this the man had seen and known . He had known all the grief, the joy, the peril and the labor such a man could know; he had grown seamed and weathered in his loyal 
service, and now, schooled by the qualities of faith and courage and humbleness that attended his labor, he had grown old, and had the grandeur and the wisdom these men have.

5. But no matter what peril or tragedy he had known, the vision of the little house and the women waving to him with a brave free motion of the arm had become fixed in the mind of the engineer as something beautiful and enduring, something beyond all change and ruin, and something that would always be the same, no matter what mishap, grief or error might break the iron schedule of his days.

6. The sight of the little house and of these two women gave him the most extraordinary happiness he had ever known. He had seen them in a thousand lights, a hundred weathers. He had seen them through the harsh bare light of wintry gray across the brown and frosted stubble of the earth, and he had seen them again in the green luring sorcery of April.

7. He felt for them and for the little house in which they lived such tenderness as a man might feel for his own children, and at length the picture of their lives was carved so sharply in his heart that he felt that he knew their lives completely to every hour and moment of the day, and he resolved that one day, when his years of service should be ended, he would go and find these people and speak at last with them whose lives had been so wrought into his own.

8. That day came. At last the engineer stepped from a train onto the station platform of the town where these two women lived. His years upon the rail had ended. He was a pensioned servant of his company, with no more work to do. The engineer walked slowly through the station and out into the streets of the town. Everything was as strange to him as if he had never seen this town before. As he walked on, his sense of bewilderment and confusion grew. Could this be the town he had passed ten thousand times? Were these the same houses he had seen so often from the high windows of his cab? It was all as unfamiliar, as disquieting as a city in a dream, and the perplexity of his spirit increased as he went on.

9. Presently the houses thinned into the straggling outposts of the town, and the streets faded into a country road-the one on which the women lived. And the man plodded on slowly in the heat and dust. At length he stood before the house he sought. He knew at once that he had found the proper place. He saw the lordly oaks before the house, the flowerbeds, the garden and the arbor, and farther off, the glint of rails.

10. Yes, this was the house he sought, the place he had passed so many times, the destination he had longed for with such happiness. But now that he had found it, now that he was here, why did his hand falter on the gate; why had the town, the road, the earth, the very entrance to this place he loved turned unfamiliar as the landscape of some ugly dreams? Why did he now feel this sense of confusion, doubt, and hopelessness?

11. At length he entered by the gate, walked slowly up the path and in a moment more had mounted three short steps that led up to the porch, and was knocking at the door. Presently he heard steps in the hall, the door was opened, and a woman stood facing him.

12. And instantly, with a sense of bitter loss and grief, he was sorry he had come. He knew at once that the woman who stood there looking at him with a mistrustful eye was the same woman who had waved to him so many thousand times. But her face pinched and meager; the flesh sagged wearily in sallow folds, and the small eyes peered at him with timid suspicion and uneasy doubt. All the brave freedom, the warmth and the affection that he had read into her gesture, vanished in the moment that he saw her and heard her unfriendly tongue.

13. And now his own voice sounded unreal and ghastly to him as he tried to explain his presence, to tell her who he was and the reason he had come. But he faltered on, fighting stubbornly against the horror of regret, confusion, disbelief that surged up in his spirit, drowning all his former joy and making his act of hope and tenderness seem shameful to him.

14. At length the woman invited him almost unwillingly into the house, and called her daughter in a harsh shrill voice. Then, for a brief agony of time, the man sat in an ugly little parlor, and he tried to talk while the two women stared at him with a dull, bewildered hostility, a sullen, timorous restraint.

15. And finally, stammering a crude farewell, he departed. He walked away down the path and then along the road toward town, and suddenly he knew that he was an old man. His heart, which had been brave and confident when it looked along the familiar vista of the rails, was now sick with doubt and horror as it saw the strange and unsuspected visage of an earth which had always been within a stone's throw of him, and which he had never seen or known. And he knew that all the magic of that bright lost way, the vista of that shining line, the imagined corner of that small good universe of hope's desire, was gone forever, could never be got back again. (Wolfe, 1935)

\section{Proposed Procedure for Discussing Literary Texts Within EFL/ESL Contexts WARM UP}

(1) Brainstorming 
Do you think that travelling by train is enjoyable? Give reasons.

(2) Advance Organizer

In what ways is the near different from the far?

READING IN ACTION

(1) As you read find out...

(a) who the word engineer refers to in American English.

(b) how the engineer felt when he met the two women.

(2) Keeping Track

(a) The engineer's work was sometimes full of danger. Give examples.

(b) "The sight of the little house and of these two women gave him the most extraordinary happiness he had ever known". Give justifications.

(c) According to the story, how is the far different from the near?

(3) Close Study: Focus on Narrator

(a) From whose point of view is the story told?

(b) Imagine you are the engineer. Tell the part of the story starting from the moment you had retired until the end.

(4) Reader's Response

(a) Do you think the man was foolish in paying a visit to the two women? Justify your answer.

(b) What do you think made the two women wave to the engineer throughout twenty years?

(c) How do you like the story? Justify your answer.

(d) Many critics believe that Wolfe's best work is to be found in his short stories. In these, he displays acute psychological insight and a talent for vivid evocation of people and places. Do you think the story displays such talents? Explain.

(5) Follow up-Library/Internet Link

Have you ever read any stories written by Wolfe? Arrange for a visit to a library or search the Internet to gather sufficient data about Wolfe's publications. Then, write up a paragraph of about 100 words mentioning what you have found.

\section{LANGUAGE PRACTICE}

(1) Word Finder

Find the words which are similar in meaning to each of the following:

(a) Care about money (paragraph 1).

(b) Going away (paragraph 2).

(c) Gathered together (paragraph 4).

(d) Looked closely (paragraph 12).

(e) Frightened (paragraph 14).

(f) Face (paragraph 15).

(2) Grammar Focus-Relative Pronouns

Relative pronouns are used to join pairs of sentences together. The following sentences are taken from the story. Re-write each sentence, using appropriate pronoun(s) or noun(s) to replace the relative pronouns.

(a) "On the outskirts of a little town upon a rise of land that swept back from the railway..." 
(b) "Before the house there were three mighty oaks which sheltered it in their clean and massive shade in summer...”

(c) "He would go and find these people and speak at last with them whose lives had been so wrought into his own".

(d) "and now, schooled by the qualities of faith and courage and humbleness that attended his labor"

(3) Literary Qualities

(a) What literary device is used in each of the following?

"and four times he had seen before him on the tracks the ghastly dot of tragedy converging like a cannon ball to its eclipse of horror at the boiler head".

"And at length the picture of their lives was carved so sharply in his heart..."

(b) What significance does the phrase "the green luring sorcery of April" (paragraph 6) have in the story?

(c) Explain how the following statement is used to effectively suggest and anticipate some points.

"And the man plodded on slowly in the heat and the dust."

\section{ORAL PRODUCTION}

Divide into two groups. Group A should support the idea that the engineer was foolish in his view of the house and its occupants, as well as in visiting them. Group B should defend the idea that the engineer was not foolish in his view of the house and its occupants, as well as in visiting them.

\section{WRITER'S WORKSHOP}

Know Your Purpose-Main Ideas/Supporting Details

The important ideas in a piece of writing are called the main ideas. Details tell us more about the main ideas.

(1) Pre-Writing. The sentence below states a main idea. Discuss four details you can use to tell more about it. There are many choices you can make to help you stay healthy.

(2) Drafting. Now write a draft of about 400 words stating the main idea; and providing appropriate supporting details.

(3) Proof-reading. Check for mistakes in sequence links, spelling and punctuation.

(4) Publishing for your Classroom Journal. Use pins to hang your piece on a line in your classroom.

\section{SELF EVALUATION}

Use the following chart to reflect on your progress in English.

\begin{tabular}{|l|l|}
\hline Skills I have acquired recently & Remarks \\
\hline & \\
\hline & \\
\hline & \\
\hline
\end{tabular}

\section{BUILDING UP YOUR PORTFOLIO}

In the poem "Ode on a Grecian Urn" Keats says: "Heard melodies are sweet, but those unheard are sweeter!” Does the meaning the poem conveys apply to the story “The Far and the Near”? Justify your answer.

\section{Conclusion}

The current paper adopts the view that literature plays an essential role in EFL/ESL contexts. Adopting 
this view, the paper seeks some convincing answers to the following questions:

(1) How can EFL/ESL practitioners maximize the effectiveness of utilizing literary texts to promote students' language proficiency?

(2) How can EFL/ESL practitioners maximize the effectiveness of utilizing literary texts through employing a stylistics approach?

As far as the first question is concerned, the author proposes that the answer key lies in exposure and practice. Students should be offered sufficient exposure to literature, as well as given adequate practice in language skills. To sufficiently answer the second question, the author believes that it is through involvement that EFL/ESL learners become well-equipped with communicative competence in English. To adequately meet this requirement, three types of involvement are required: affective, cognitive, and interactive. Students need to be involved affectively, cognitively, and interactively with the literary text being dealt with.

Based on the aforementioned answers, the questions to raise accordingly would normally be concerned with what and how. Which literary texts should students be exposed to and have practice in? Amongst the essential criteria which the author believes need to be emphasized when selecting a literary text for teaching purposes are: students' language proficiency level, cultural appropriateness, variety, appropriate length, authenticity, relative contemporary, and age group's common interest. Concerned with the question how, that is to say, methodology, it is the author's belief that the language instructor is the key to effective teaching. An experienced instructor's knowledge and skill regarding methods of instruction may be compared to a technician's toolbox. The instructor's tools are teaching methods. Just as the technician uses some tools more than others, the instructor will use some methods more often than others. The instructor's success, the author believes, is determined to a large degree by the ability to organize material as well as select and utilize a teaching method appropriate to a particular teaching situation. All instructional approaches should testify to eclecticism when it comes to choosing an appropriate methodological approach to take with a group of students. As Carter (2010) argued:

The appropriate method is very much a hands-on approach taking each text on its own merits, using what the reader knows, what the reader is aiming for in his or her learning context, and employing all of the available tools, both in terms of language knowledge and methodological approaches. (p. 117)

To end with, it would be appropriate to view literature as an effective device which EFL/ESL practitioners can utilize, to enhance not only language skills but also cultural awareness and critical thinking. To meet today's requirements, the selection process of appropriate literary texts, the adoption of effective approaches and strategies, and the implementation of purposeful curriculum, will all yield in quality education for all to learn and gain.

\section{References}

Busse, B. (2010). Recent trends in new historical stylistics. In D. Mclntyre \& B. Busse (Eds.), Language and style (pp. 32-54). London: Palgrave Macmillan.

Busse, B., \& Mclntyre, D. (2010). Language, literature and stylistics. In D. Mclntyre \& B. Busse (Eds.), Language and style (pp. 3-12). London: Palgrave Macmillan.

Carter, R. (2010). Methodologies for stylistic analysis: Practices and pedagogies. In D. Mclntyre \& B. Busse (Eds.), Language and style (pp. 55-68). London: Palgrave Macmillan.

Cook, G. (2003). Applied linguistics. Oxford, UK: Oxford University Press.

Crawshaw, R. (1996).The boundaries of style and stylistics. Modern Language Review, 91(2), 273-280. 
Leech, G. (2010). Analysing literature through language: Two Shakespearian speeches. In D. Mclntyre \& B. Busse (Eds.), Language and style (pp. 15-31). London: Palgrave Macmillan.

Short, M. H. (1983). Stylistics and the teaching of literature. ELT Documents, 17(3), 67-84.

Stockwell, P. (2007). On teaching literature itself. London, UK: Palgrave Macmillan.

Warner, C. (2010). Using literary pragmatics to teach language as culture: The case of Young Werther. Paper presented at the 30th PALA International Conference, University of Genoa, Genoa.

Wolfe, T. (1935). The far and the near. Retrieved from http://www.readfirst.net/wolfe.html

Zyngier, S., \& Fialho, O. (2010). Pedagogical stylistics, literary awareness and empowerment: A critical perspective. Language and Literature, 19(1), 13-33. 